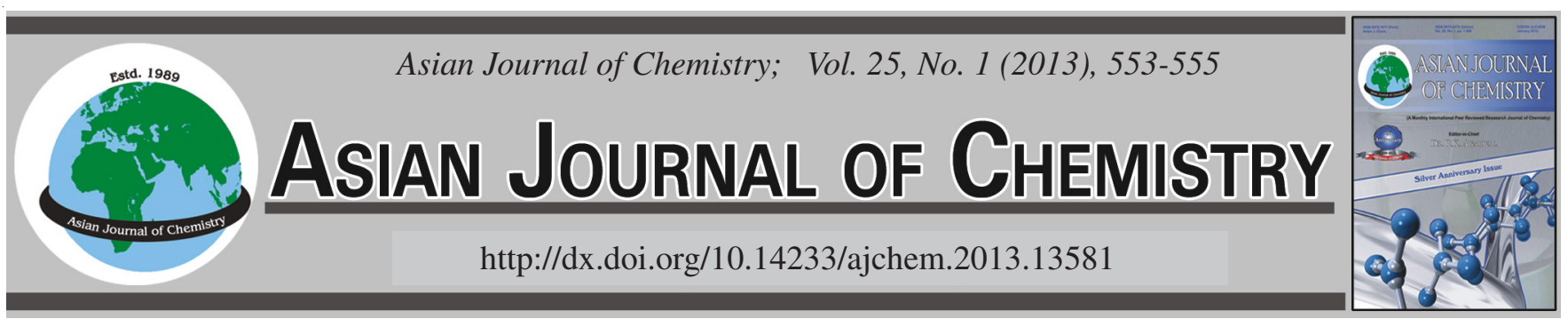

\title{
Fumigant Toxicity of the Essential Oils from Medicinal Plants Against Bean Weevil, Acanthoscelides obtectus (Say) (Coleoptera: Bruchidae)
}

\author{
ERDAL SERTKAYA \\ Department of Plant Protection, Agriculture Faculty, Mustafa Kemal University, 31034 Antakya, Hatay, Turkey \\ *Corresponding author: Fax: +90 326245 5832; Tel: +90 326245 5845; E-mail: esertkaya@ mku.edu.tr
}

\begin{abstract}
Fumigant activity of essential oil vapours from the aromatic plants such as, wild thyme (Thymus serpyllum L., Lamiaceae), origanum (Origanum onites L., Lamiaceae), rosemary (Rosmarinus officinalis L, Lamiaceae), basil (Ocimum basilicum L., Lamiaceae) and lemon balm (Melissa officinalis L., Lamiaceae) against the bean weevil Acanthoscelides obtectus (Say) adults under laboratory conditions. Volatile phase effects of different concentrations of the essential oils were used to determine insecticidal activities. Laboratory bioassay results indicated that all essential oils were found to cause $100 \%$ adult mortality of $A$. obtectus in a dose-dependent manner. Essential oils of thyme and origanum had the highest insecticidal effects, causing high adult mortalities at the lower concentration $\left(10 \mu \mathrm{g} \mathrm{mL} \mathrm{air}^{-1}\right.$ in comparison to other essential oils tested. Adult viability was totally affected by essential oils of rosemary, basil and lemon balm at the concentrations of 20,30 and $30 \mu \mathrm{g} \mathrm{mL} \mathrm{m}^{-1}$ air, respectively. The estimated $\mathrm{LC}_{50}$ (lethal concentration 50 ) values obtained for each essential oil were calculated by using probit analysis. The lowest $\mathrm{LC}_{50}$ values were recorded for thyme essential oil $\left(1.12 \mu \mathrm{g} \mathrm{mL} \mathrm{m}^{-1}\right)$ was followed by origanum $\left(1.31 \mu \mathrm{g} \mathrm{mL}^{-1}\right)$, rosemary $\left(2.66 \mu \mathrm{g} \mathrm{mL}^{-1}\right)$, basil $\left(3.10 \mu \mathrm{g} \mathrm{mL} \mathrm{L}^{-1}\right)$ and lemon balm $\left(3.60 \mu \mathrm{g} \mathrm{mL} \mathrm{m}^{-1}\right)$ respectively. The results of the present study concluded that plant essential oils could be useful in promoting research aiming at the development of new agent for pest control from the plants with medicinal values.
\end{abstract}

Key Words: Acanthoscelides obtectus, Stored pest, Essential oil, Insecticidal, Biopesticide.

\section{INTRODUCTION}

Stored products of agricultural and animal origin are attacked by more than 600 species of beetle pests, 70 species of moths and about 355 species of mites causing quantitative and qualitative losses ${ }^{1}$ and insect contamination in food commodities is an important quality control problem of concern for food industries. Among the insects attacking stored products, members of Bruchidae have attracted the attention of many scientists not only because they can easily be manipulated but also because of the economic importance they have. Bean weevil, A. obtectus with its physiological adaptability, is one of the most destructive pests of Phaseolus vulgaris L. (kidneybean) which is one of the most important food pulses in the Mediterranean countries. Pest damage by this species has been estimated to cause $20-40 \%$ loss of stored seeds per annum ${ }^{2}$.

Fumigation plays a major role in insect pest elimination in stored products. Previously, phosphine and methyl bromide were the two common fumigants used for stored-product protection world wide. Insect resistance to phosphine is a global issue now and control failures have been reported in field situations in some countries ${ }^{3,4}$. Methyl bromide, a broadspectrum fumigant, has been declared an ozone-depleting substance and therefore, is being phased out completely. In view of the problems with the current fumigants, there is a global interest in alternative strategies including development of chemical substitutes, exploitation of controlled atmospheres and integration of physical methods ${ }^{5}$.

Plant essential oils and their major components, various monoterpenoids, show a broad spectrum of activity against insects, mites and various arthropods $s^{6,7}$. These compounds act as antifeedants and repellents while they may also affect some biological parameters such as growth rate, life span and reproduction ${ }^{7-12}$. Their vapour action may also be very promising for pest control because of their insecticidal properties and the fact that they can act as fumigants.

The objective of the present work was to investigate the fumigant activity of essential oil vapours from the aromatic plants wild thyme (Thymus serpyllum L., Lamiaceae), origanum (Origanum onites L., Lamiaceae), rosemary (Rosmarinus officinalis L, Lamiaceae), basil (Ocimum basilicum L., Lamiaceae) and lemon balm (Melissa officinalis L., Lamiaceae) against $A$. obtectus adults. 


\begin{tabular}{|c|c|c|c|c|c|}
\hline \multicolumn{6}{|c|}{$\begin{array}{l}\text { TABLE-1 } \\
\text { EFFECTS OF DIFFERENT CONCENTRATIONS OF VOLATILE PHASES OF } \\
\text { ESSENTIAL OILS ON PERCENT MORTALITY OF A. obtectus ADULTS }\end{array}$} \\
\hline \multirow{2}{*}{$\begin{array}{l}\text { Concentrations } \\
\left(\mu \mathrm{g} \mathrm{mL}^{-1} \text { air }\right)\end{array}$} & \multicolumn{5}{|c|}{ Essential oils and \% mortality } \\
\hline & T. speyllum & O. onites & R. officinalis & O. basilicum & M. officinalis \\
\hline 0.0 & $0,0 \mathrm{a}$ & $0,0 \mathrm{a}$ & $0,0 \mathrm{a}$ & $0,0 \mathrm{a}$ & $0,0 \mathrm{a}$ \\
\hline 1.0 & $46,7 \mathrm{bB}$ & $40,0 \mathrm{bB}$ & $23,4 \mathrm{bA}$ & $23,3 \mathrm{bA}$ & $20,0 \mathrm{bA}$ \\
\hline 2.0 & $73,3 \mathrm{cB}$ & $66,6 \mathrm{cB}$ & $43,3 \mathrm{cA}$ & $40,0 \mathrm{cA}$ & $36,7 \mathrm{cA}$ \\
\hline 5.0 & $96,7 \mathrm{~dB}$ & $93,2 \mathrm{~dB}$ & $63,2 \mathrm{dA}$ & $56,7 \mathrm{dA}$ & $53,3 \mathrm{dA}$ \\
\hline 10.0 & $100,0 \mathrm{~dB}$ & $100,0 \mathrm{~dB}$ & $80,0 \mathrm{deA}$ & $73,3 \mathrm{eA}$ & $66,6 \mathrm{eA}$ \\
\hline 15.0 & $100,0 \mathrm{~dB}$ & $100,0 \mathrm{~dB}$ & $93,3 \mathrm{efAB}$ & $86,6 \mathrm{fAB}$ & $83,4 \mathrm{fA}$ \\
\hline 20.0 & $100,0 \mathrm{dA}$ & $100,0 \mathrm{dA}$ & $100,0 f A$ & $96,7 \mathrm{gA}$ & $96,6 \mathrm{gA}$ \\
\hline 30.0 & $100,0 \mathrm{~d}$ & $100,0 \mathrm{~d}$ & $100,0 \mathrm{f}$ & $100,0 \mathrm{~g}$ & $100,0 \mathrm{~g}$ \\
\hline $\mathrm{LC}_{50}$ & 1,12 & 1,31 & 2,66 & 3,10 & 3,60 \\
\hline $\mathrm{LC}_{90}$ & 3,19 & 3,83 & 11,96 & 16,67 & 19,14 \\
\hline
\end{tabular}

\section{EXPERIMENTAL}

Acanthoscelides obtectus adults were obtained from laboratory cultures maintained on bean, Phaseolus vulgaris $\mathrm{L}$, at $25( \pm 1){ }^{\circ} \mathrm{C}, 65( \pm 5) \%$ relative humidity and a photoperiod of 8:16 h light: dark. The insects were collected from a warehouse in Hatay province and the beans were purchased from the local market and maintained in a freezer at $-20^{\circ} \mathrm{C}$.

The plants used in this study were identified by Dr. I. Uremis. A voucher specimen has been deposited in the herbarium of the plant protection department, MKU (No. TspyYD7, OoAS56, RoBK40, ObRY15 and MelAM23). For the extraction of essential oils, plants were collected from Yayladagi, Serinyol, Reyhanli and Antakya districts of Hatay provinces situated in the Eastern Mediterranean region of Turkey. Air-dried plant material (200 g) was placed in a $5 \mathrm{~L}$ round-bottom distillation flask and $3 \mathrm{~L}$ double distilled water added. The essential oils were obtained by steam distillation for $3 \mathrm{~h}$ using Clevenger-type apparatus (Ildam, Ankara). The oils were separated, dried over anhydrous sodium sulphate and stored in an amber bottle at $4{ }^{\circ} \mathrm{C}$ until used.

Toxicity tests: Transparent acrylic cups $(6 \mathrm{~cm}$ height and $3.5 \mathrm{~cm}$ diameters, which offer $50 \mathrm{~mL}$ air space) were used as test chambers for determination of volatile phase effects of the essential oils. Ten bean seeds without insects were individually placed into the chamber. Ten adult insects were introduced in each cup and allowed to settle for half an hour before exposure to essential oil. The top of the insect chamber was covered by using the lids. The essential oils were applied with a micropipette on a filter paper strip $(3 \mathrm{~cm} \times 1 \mathrm{~cm})$ attached to the lids. Different concentrations of essential oil were prepared by dissolving the requisite amounts in sterile dimethyl sulfoxide (DMSO) solution. Essential oils were diluted from the concentration of $15000 \mu \mathrm{g}$ to $500 \mu \mathrm{g} \mathrm{mL} \mathrm{m}^{-1}$ in DMSO and a $10-\mu \mathrm{L}$ aliquot of each concentration was added on the inner surface of the lid of test chamber with a micropipette giving concentrations of 1, 2, 5, 10, 15, 20 and $30 \mu \mathrm{g} \mathrm{mL}^{-1}$ air. Insect chambers were sealed immediately with parafilm to prevent loss of essential oils from the chamber. Three replications were made for each concentration. As untreated control, three cups containing only $10 \mu \mathrm{L}$ of DMSO were used.

The treated insect-chambers were returned to the incubator set at $25^{\circ} \mathrm{C}, 60-65 \%$ relative humidity and a photoperiod of 16:8 (L:D) h. Mortality was determined under a dissecting microscope $24 \mathrm{~h}$ after treatment. Adult insects were assessed for $30 \mathrm{~min}$ for mobility and for $2 \mathrm{~h}$ for mortality, defined by lack of response to stroking with a paintbrush.

Data analysis: Mortality observations were analyzed by using the SPSS program, version 11.5, for ANOVA. Tukey's test was used to compare means. Probit analysis was used to determine lethal concentrations $\left(\mathrm{LC}_{50}\right)$, by using the SPSS program, version 11.5. Abbott's formula was used to correct mortality in controls.

\section{RESULTS AND DISCUSSION}

The volatile phase effects of different concentrations of essential oils on the mortality of $A$. obtectus adults are shown in Table-1. All essential oils were found to cause $100 \%$ adult mortality of A. obtectus in a dose-dependent manner. Essential oils of thyme had the highest insecticidal effects, causing high adult mortalities at the lower concentrations in comparison to the other essential oils tested. Adult viability was totally affected by thyme, origanum, rosemary, basil and lemon balm at the concentrations of $10,10,20,30$ and $30 \mu \mathrm{g} \mathrm{mL}^{-1}$ air, respectively. The $\mathrm{LC}_{50}$ (lethal concentration 50) was the concentration of the essential oil, which kills $50 \%$ of adult insect within $24 \mathrm{~h}$ following exposure. The estimated $\mathrm{LC}_{50}$ values obtained for each essential oil were calculated by using probit analysis (Table-1). The lowest $\mathrm{LC}_{50}$ values were recorded for thyme essential oil $\left(1.12 \mu \mathrm{g} \mathrm{mL}^{-1}\right)$ was followed by origanum $(1.31$

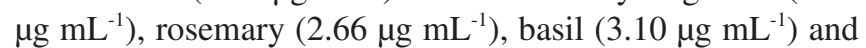
lemon balm $\left(3.60 \mu \mathrm{g} \mathrm{mL} \mathrm{m}^{-1}\right)$.

Botanical insecticides have long been recommended as attractive alternatives to synthetic chemical insecticides for pest management because these chemicals pose little threat to the environment or to human health ${ }^{7}$. In previous studies, volatile compounds from essential oils were reported to posses antimicrobial activity against a variety of food borne, human 
and plant pathogens and pest $\mathrm{t}^{12}$. Pyrethrum and neem are well established commercial pesticides based on plant essential oils and recently entered the marketplace.

In previous study, insecticidal efficacy of essential oils, derived from taxonomically different medicinal plants species, such as Salvia officinalis, Cuminum cyminum, Anetheum graviolens, Mentha spicata spicata, Micromeria fruticosa and Ocimum minimum were investigated against three important stored product insects, including A. obtectus, Sitophilus granarius and Sitophilus oryzae under laboratory conditions ${ }^{13}$. In their results the lowest $\mathrm{LC}_{50}$ value against $A$. obtectus was recorded for $C$. cyminum essential oil $\left(0.029 \mu \mathrm{L} \mathrm{mL}^{-1}\right)$. In another study, the chemical composition and insecticidal action of the essential oils isolated from various parts of three aromatic plants (Lavandula hybrida Rev, Rosmarinus officinalis L and Eucalyptus globulus Labill) was determined on $A$. obtectus adults and their $\mathrm{LC}_{50}$ values were estimated by Papachristos et al. ${ }^{14}$. Several authors have reported that all essential oils tested exhibited strong activity against $A$. obtectus adults, with varying $\mathrm{LC}_{50}$ values depending on the essential oils. Greater susceptibility of A. obtectus to essential oils and monoterpenoids has also been reported ${ }^{2,14,15}$. In another study, which was conducted by Karaborklu et al. ${ }^{16}$, the mean longevity of $A$. obtectus adults was significantly decreased depending on the increasing doses of savory, myrtle, marjoram, laurel, lemon, tansy and sage essential oils.

To our knowledge, our results is the first study demonstrating that the essential oils of T. serpyllum, O. basilicum and M. officinalis possess insecticidal activities against $A$. obtectus.

The number of compounds and their relative amount found in plant essential oils varied according to plant species and the particular compound. The major compounds found in essential oils of thyme, origanum, rosemary, basil and lemon balm were carvacrol, carvacrol, borneol, linalool and citronellal respectively ${ }^{17-20}$. These compounds have previously been reported to have antimicrobial activity against a variety of insects, mites, weeds and plant pathogens ${ }^{12,21,22}$.

Major components of essential oils such as monoterpenoids, carvacrol, 1,8-cineole, $p$-cymene, menthol, $\gamma$-terpinene, terpinen-4-ol and thymol were investigated against three stored product insects ${ }^{15,23-25}$. Authors have reported that these individual components possess insecticidal, fecundity, antifeeding and oviposition deterant effect against different major stored product insects ${ }^{26,27}$. In this aspect, insecticidal activities of essential oils used in our study on adult bean weevil mortalities could be due to the fumigant toxicities of the major components of essential oils.

In previous studies, in addition to insecticidal activities, essential oils derived from medicinal plants possess antifungal, antibacterial, herbicidal and acaricidal activities against plant pathogenic fungi, bacteria, weeds and mites ${ }^{28-30}$.

In conclusion, essential oils from medicinal plants growing in the region can offer good control of A. obtectus adults. Natural insecticides are a desirable alternative to synthetic pesticides because they have low toxicity in mammals, little environmental effect and wide public acceptance. In this aspect, essential oils of plants may play an important role in the storedproducts protection and reduce the risks associated with the use of highly toxic fumigants. The essential oils tested in this study could be considered as potential alternatives for highly toxic fumigants with modification as their structures could lead to the development of new classes of insecticide compounds. However, further experiments are needed to elucidate the efficacy of these substances in large-scale applications, their fumigant properties.

\section{REFERENCES}

1. S. Rajendran, in ed.: D. Pimentel, Postharvest Pest Losses, Encyclopedia of Pest Management. Marcel Dekker, Inc., New York, pp. 654-656 (2002).

2. C. Regnault-Roger and A. Hamraoui, Crop. Protect., 13, 624 (1994).

3. R.W.D Taylor, Int. Pest Cont., 31, 10 (1989).

4. P.J. Collins, G.J. Daglish, H. Pavic, T.M. Lambkin and R. Kapittke, in eds.: E.J. Wright, H.J. Banks and E. Highley, Combating Strong Resistance to Phosphine in Stored Grain Pests in Australia, Stored Grain in Australia 2000. Proceedings of the Australian Postharvest Technical Conference, Adelaide, 1-4 August 2000. CSIRO Stored Grain Research Laboratory, Canberra, Australia, pp. 109-112 (2002).

5. MBTOC, Report of the Methyl Bromide Technical Options Committee (MBTOC) Assessment. UNEP, Nairobi, Kenya (2002).

6. C. Regnault-Roger, Integr. Pest Manag. Rev., 2, 25 (1997).

7. M.B. Isman, Ann. Rev. Entomol., 51, 45 (2006).

8. A. Ayvaz, S. Karaborklu and O. Sagdic, Asian J. Chem., 21, 596 (2009).

9. E. Enan, Comp. Biochem. Physiol. C., 130, 325 (2001).

10. Y. Akhtar and M.B. Isman, J. Appl. Entomol., 128, 32 (2004).

11. I. Aslan, S. Kordali and O. Calmasur, Fresenius Environ. Bull., 14, 413 (2005).

12. F. Bakkali, S. Averbeck, D. Averbeck and M. Waomar, Food Chem. Toxicol., 46, 446 (2008).

13. O.C. Karakoc, A. Gokce and I. Telci, Türk. Entomol. Derg., 30, 123 (2006).

14. D.P. Papachristos, K.I. Karamanoli, D.C. Stamopoulos and U. MenkissogluSpiroudi, Pest. Manag. Sci., 60, 514 (2004).

15. C. Regnault-Roger and A. Hamraoui, J. Stored Prod. Res., 31, 291 (1995).

16. S. Karaborklu, A. Ayvaz and S.Yilmaz, Pak. J. Zool., 42, 679 (2010).

17. E.M. Soylu, S. Soylu and S. Kurt, Mycopathologia, 161, 119 (2006).

18. E. Sertkaya, K. Kaya and S. Soylu, Asian J. Chem., 22, 2982 (2010a).

19. A.D. Duman, I. Telci, K.S. Dayisoylu, M. Digrak, I. Demirtas and M.H. Alma, Nat. Prod. Commun., 5, 969 (2010).

20. A.I. Hussain, F. Anwar P.S. Nigam, S.D. Sarker, J.E. Moore, J.R. Rao and A. Mazumdar, Food Sci. Technol., 44, 1199 (2011).

21. E.H. Koschier, Nat. Prod. Commun., 3, 1171 (2008).

22. S. Kordali, A. Cakir, H. Ozer, R. Cakmakci, M. Kesdek and E. Mete, Bioresour. Technol., 99, 8788 (2008).

23. A. Hamraoui and C. Regnault-Roger, Acta Bot. Gallica, 144, 413 (1997).

24. V. Rozman, I. Kalinovic and Z. Korunic, J. Stored Prod. Res., 43, 349 (2007).

25. G.P.P. Kamatou and A.M. Viljoen, Nat. Prod. Commun., 3, 1183 (2008).

26. D.C. Stamopoulos, J. Stored Prod. Res., 27, 199 (1991).

27. D.P. Papachristos and D.C. Stamopoulos, J. Stored. Prod. Res., 38, 117 (2002)

28. E. Sertkaya, K. Kaya and S. Soylu, Ind. Crop. Prod., 31, 107 (2010b).

29. S. Soylu, G.A. Evrendilek and E.M. Soylu, Ital. J. Food Sci., 21, 347 (2009).

30. E.M. Soylu, S. Kurt and S. Soylu, Int. J. Food Microbiol., 143, 183 (2010). 